Uşak Üniversitesi Sosyal Bilimler Dergisi

$2014,7 / 4$

\title{
Tüketici Algılarını Etkileyen Faktörlerde Sosyal Medyanın Rolü: Niğde Üniversitesi İ.İ.B.F. Örneği
}

\author{
Murat TOKSARI* \\ Mehmet MÜRÜTSOY* \\ Muhammet BAYRAKTAR ${ }^{* * *}$
}

\begin{abstract}
Özet
Günümüzde işletmeler kendilerini yoğun ve acımasız bir rekabetin tam ortasında bulmaktadır. Böylesine bir rekabet ortamında tüketici davranışlarının yakından izlenmesi, tüketici davranışlarını etkileyen yeni faktörlerin tespit edilip buna göre pazarlama politikalarının belirlenmesi işletmelerin başarı çıtasını daha da üst düzeylere yükseltecektir. İnternet teknolojisindeki meydana gelen hızlı değişmeler yaşamın her alanında olduğu gibi tüketicilerin tüketim davranışlarında da kendini göstermektedir. Bu sebeple işletmeler tüketicilerin algılarını etkileyen faktörleri daha etkin ve verimli kullanmak için tutundurma karması bileşenlerinden epazarlamanın önemli bir unsuru olan sosyal medya araçlarını rekabet gücü olarak kullanmaktadırlar. Sosyal medya, kullanıcılarının kendilerini daha iyi ifade ettikleri, etkileşim içinde oldukları kullanıcılar ile fikir ve görüşlerini paylaştıkları online bir ortam olarak ifade edilmektedir.

Bu çalışmanın amacı tüketici davranışlarını etkileyen faktörlerden sosyal medyanın rolünü tespit etmektir. Bu amaçtan yola çıkarak tüketici davranışları, tüketici davranışlarını etkileyen faktörler, tüketicilerin algılarını etkileyen faktörler incelenecek sosyal medyanın tüketici davranışları üzerindeki etkinliği ölçülmeye çalışılacaktır. Bu etkinliği ölçmek için Niğde Üniversitesi İktisadi ve İdari Bilimler Fakültesi öğrencilerine yönelik nicel veri toplama yöntemlerinden anket yöntemi kullanılarak veriler toplanmış ve elde edilen veriler SPSS paket programlarından faydalanılarak istatistiki açıdan analiz edilmiştir.
\end{abstract}

Anahtar Kelimeler: Tüketici Davranışları, Sosyal Medya, Sosyal Medya Pazarlaması.

\footnotetext{
*Yrd. Doç. Dr., Niğde Üniversitesi İ.İ.B.F., İşletme Bölümü

** Doktora Öğrencisi, Niğde Üniversitesi, Sosyal Bilimler Enstitüsü

**** Doktora Öğrencisi, Niğde Üniversitesi, Sosyal Bilimler Enstitüsü
} 


\title{
The Role of Social Media in Factors Affecting Consumer Perception: Nigde University I.I.B.F. Instance
}

\begin{abstract}
Today, businesses find themselves in the middle of intense and fierce competition. In such a competitive situation, close observation of consumer behavior, identification of marketing strategies accordingly by determining new factors that affect the consumer behavior will increase the success in to consumer levels. As in the every aspect of life, the rapid changes in the internet technology affects the consumers' consumption behavior.

To measure the effectiveness of this method, the students of the faculty of Economics and Administration Science will be applied the survey method, one of the quantitative methods, by using this data was be collected and obtained data was be analyzed statistically by using SPSS package programe.

Key Words: Consumer Behaviors, Social Media, Social Media Marketing.

\section{Giriş}

Tüketici davranışları duygu ve düşünce pratiğini ve tüketim sürecinde ki eylemleri içermektedir. Aynı zamanda bu duygu, düşünce ve eylemleri etkileme gücünü sahip çevredeki bütün şeyleri de içerir. Örneğin diğer müşterilerin yorumları, reklamlar, fiyat bilgisi, ambalajlama, ürünün dış görüşü gibi etmenler tüketici davranışlarını etkilemektedir. İnternet teknolojisindeki gelişmelere paralel olarak ortaya çıkan ve dünyada milyarlarca aktif kullanıcıya ulaşan sosyal medya günümüzde tüketici davranışlarını etkileyen yeni bir faktör olarak ortaya çıkmıştır. İşletmelerin tüketicilerle, tüketicilerin ise birbirleriyle arasındaki iletişim eskiye oranla sosyal medya ile birlikte daha güçlü bir hale gelmiştir.

Sosyal medya farklı insanları bir araya getirirken bu insanların algilarına, tutumlarına ve son davranışlarına etki etmektedir. Online ortamlarda aynı görüşe sahip üyelerle etkileşim kurmaktan hoşlandıklarından ve sosyal bağ oluşturma ve aidiyet gereksinimlerini karşılamak istediklerinden online topluluklara katkıda bulunmak, yeni şeyler ortaya çıkarmak ve bu toplulukların birer üyesi olmak fikrini insanlar memnuniyetle kabul etmiştir (Laroche, 2012). Sosyal medya insanlara görüşlerini açıklayabileceği, fikir alışverişi yapabileceği, sanal bir ortam
\end{abstract}


sağlamaktadır. Tüketicilerin sosyal medyada bir ürünle ilgili olarak yaptıkları yorumlar olumlu ya da olumsuz marka algısı oluşturmakta ve bu yorumlar tüketicilerin kararlarını etkilemektedir (Chung ve Austria, 2010:581).

$\mathrm{Bu}$ çalışmanın amacı tüketicilerin algılarını etkileyen faktörlerde sosyal medyanın rolünü belirlemeye çalışmaktır. Bu amaçtan yola çıkarak tüketici davranışları, tüketici davranışlarını etkileyen faktörler ve tüketicilerin algılarını etkileyen faktörler incelenerek sosyal medyanın tüketici davranışları üzerindeki etkinliği ölçülmeye çalışılmıştır. Bu etkinliği ölçmek için Niğde Üniversitesi İktisadi ve İdari Bilimler Fakültesi öğrencilerine yönelik veri toplama yöntemlerinden anket çalışması yapılmak suretiyle veriler toplanmış ve elde edilen veriler SPSS paket programından faydalanılarak istatistiki açıdan analiz edilmiştir.

\section{Tüketici Algılarını Etkileyen Faktörler}

Günümüz dünyasında insanların alış veriş alışkanlıkları sürekli değişkenlik göstermektedir. İşletmeler bu alışkanlıklara çözüm üretmek için bir takım politikalar geliştirmişlerdir. Bunlar işletmelerin kontrol edemediği ancak alım satım kararlarında mutlaka dikkate almaları gerektiği sosyal faktörler (kültür, alt kültür, sosyal sınıf, refereans grupları, roller, aile), psikolojik faktörler (güdüleme, algı, öğrenme, kişilik), kişisel faktörler (demografik ve durumsal faktörleri) bilmeleri ve tüketici olarak ifade edilen insanların alış veriş alışkanlıklarını, satın alma davranışlarını gözlemleyerek etkili bir pazarlama politikası çabası içine girmeleri gerekmektedir.

$\mathrm{Bu}$ doğrultuda, işletmeler pazarlama bileşenlerini etkin uygulayabilmeleri için hedef kitledeki tüketicileri ve pazarı iyi tanıyarak tüketicilerin özelliklerine uygun pazarlama bileşenlerini geliştirmeleri gerekmektedir (Karabulut,1989:3). Pazarlama yöneticileri, kontrol altındaki pazarlama bileşenlerini hedef kitledeki pazar ile uyumlu bir hale getirerek tüketicilerin davranışsal tepkilerini kendi amaçları doğrultusunda yönlendirmek istemektedir. İşletmelerin amaçlarına erişip erişmedikleri bu başarı kriterleri ile değerlendirilmektedir. Tüketici davranışlarının analiz edilip onlara uygun ürün ve hizmetlerin üretilmesi, tüketicilerin daha iyi anlaşıldığı anlamına gelir (İslamoğlu ve Altunışık, 2010:7).

$\mathrm{Bu}$ süreçte etki altına alınmak istenen tüketicilerin istek, ihtiyaç ve arzularının ortaya çıkarılması gerekmektedir. Bunları başarabilmenin yolu ise, tüketicilerin algılarını etkileyen faktörlerin neler olduğunun tespit edilmesiyle olur. 
Tüketicicilerin algılarını etkileyen faktörler, fiziksel görünüm, sterotipler, ilk etki, halo etkisi, sonuçlara siçramak ve işaret semboller olmak üzere altı kısma ayrılmıştır. Bunlar;

- Fiziksel görünüm: Ürün veya markaların tüketicilerin algılarını olumlu yönde etkilemesi için fiziksel görünümün ikna edici olması ve tüketicilerin tutumlarına uygun olması gerekmektedir.

- Sterotipler: Katı (stereos) ve nitelik, tip (typos) kelimelerinden meydana gelen stereotip terimini ilk defa 1922 yılında Lippman kullanmış ve tüketicilerin beynindeki ürün ve markaların imajlarını ön plana çıkarmayı amaçlamıştır. Stereotip, insanların önyargılı olmasını sağlamakta ve önyargıları besleyip koruyan bir işleve sahip olmaktadır. (http://www.msxlabs.org/forum/psikoloji-ve-psikiyatri). Kişilerin değişik uyarıcıların anlamıla ilgili olarak akıllarında önceden oluşan resimleri taşırlar. Örneğin, günümüzde "kadının yeri mutfaktır" düşüncesinin yerine "çalışan ve özgür kadın" tiplemesi reklamcılar tarafından kullanılmaktadır (Odabaşı ve Fidan, 200: 135).

- İlk Etki: Birbirleriyle ilk defa karşılaşan insanlar otuz otuzbeş saniye gibi kısa bir süre içerisinde birbirleri hakkında olumlu, olumsuz, güvenilir, güvenilir değil, iyi, kötü gibi değerlendirmede bulunmaktadır (http://hbogm.meb.gov.tr). İlk etki fiziksel görünüm, konuşma tarzl, vücut hareketleri ile oluşturulmaktadır. Zeka derecesi, yetenekli oluş, güvenilirlik, sosyal tabaka, maddi durum, çekicilik daha sonraki iletişim süreçlerinde anlaşılmaktadır (Keklik, 2012:131). İnsanların giyim kuşamları ilk izlenimin oluşmasında etkili olmaktadır. Örneğin yeni ürünlerin pazara sunulmasında her şeyin mükemmel olması gerekmektedir. Çünkü sorunların ilk etkisini değiştirmek oldukça zordur (Odabaşı ve Gülfidan, 2002: 135).

- Sonuçlara Sıçramak: Tüketicilerin, reklamların sadece başlangıcını izleyerek ve sınırlı bilgilere dayanarak ürün hakkında sonuçlar çıkartabilmesidir (Odabaşı ve Gülfidan, 2002: 135).

- Halo Etkisi: Toplum içerisinde birçok kişi için farklı değerlendirmelerde bulunulmaktadır. Kimileri için iyiliği yüzüne yansımış, temiz yüzlü bir insan ifadeleri kullanılırken kimileri içinse söylediği kötü bir söz karşısında söylenen sözün o kişiye 
yakışmadığı ifade edilmektedir. Bazı insanlar ise ne yaparsam yapayım yine de karşımdaki kişiye yaranamıyorum şeklinde serzenişte bulunmaktadır. Bu tür değerlendirmeler algısal psikolojide halo etkisine dikkatleri çekmektedir (Akçay, 2013:68). İş ortamında da halo etkisinden kaynaklanan hatalar yapılmakta yöneticiler iş görenlerin tek bir yönünü dikkate alarak onları değerlendirmekte ve bu tür hatalara zemin hazırlamaktadırlar (Helvac1, 2002:161).

- İşaret ve Semboller: Kişilerin duyumlarına sunulan uyarıcıları yorumlamaları algılamalarını kolaylaştırır. Elmanın Apple bilgisayarlarını, Temel Reis ıspanağı vb. anımsatması örnek olarak verilebilir (Odabaşı ve Gülfidan, 2002: 135).

\section{Sosyal Medya ve Sosyal Medya Pazarlaması}

Son on yılda teknolojideki muazzam dönüşüm geleneksel pazarlama yaklaşımlarının keskin bir biçimde değiştirilmesi gerekliliğini ortaya çıkardı ve pazarlamacılar için yeni bir çağ başlattı. Bu yeniçağ ile birlikte medya kavramı ve işletmelerin tüketicilerle olan iletişimleri bir dönüşüme uğradı.

Geleneksel terminolojide medya, mesajı gönderen ile diğerleri arasındaki iletişiminin nasıl yapıldığı bağlamında ifade edilirken, günümüzde online uygulamalara bağlı olarak, medyanın yeni formu sadece mesajı gönderenin diğerleriyle iletişimine olanak sağlamakla kalmayıp, mesaj gönderilenlerinde iletişime dahil olmasını sağlamıştır. Örneğin televizyon, radyo, gazete, dergi gibi geleneksel medya araçlarında mesaj birçok insana gönderiliyordu ve çoğunlukla bu mesajları insanlar görmezden geliyordu. Bloglar, wikiler, online topluluklar gibi yeni medya araçları ile birlikte insanlar mesaj gönderenlerle gerçek zamanlı bir iletişim kurma olanağına sahip olmakla kalmayıp aynı zamanda bu mesajlarla ilgili olarak diğer insanlarla fikir alışverişi yapma imkanına kavuştular (Deepa ve Deshmukh, 2013: 2461-2462).

Pazarlama iletişimi ise, kitle iletişim araçlarının ilettiği tek yönlü mesajlardan sosyal medya platformlarındaki hedef tüketici kitlelerine mesajların direkt olarak iletildiği iki yönlü iletişime dönüştü (Gillin, 2009).

Günümüzden yaklaşık 10 sene önce LinkedIn'in 2003 yılında kurulmasıyla başlayan sosyal medya çağı olarak adlandırılan bu yeni medya çağını 2004 yılında MySpace ve Facebook, 2005'te YouTube, 2006'da Twitter'ın kurulması takip etti. On yıldan daha kısa bir süre içinde sosyal medyanın popülerliği çok hızlı bir şekilde arttı ve dünya genelinde milyarlarca insana ulaştı (Curtis, 2011). Örneğin günümüzde Facebook 1 
milyardan fazla kullanıcıya, LinkedIn'in 259 milyon kullanıcıya Google+ 300 milyon kullanıcıya ve twitter 500 milyon kullanıcıya ulaşmış durumda. 1 milyar kullanıcısı olan YouTube'de günlük olarak videoların toplam görüntülenme sayısı 4 milyara ulaşmakta.

Yeni medya çağı olarak isimlendirilen sosyal medya temelde iletişim ile ilgili bir kavramdır. Çoğu zaman ortak ilgi alanlarından dolayı insanlar bir arada görülmektedir. İnsanların toplanmayı ve paylaşmayı sevdiği ortak bir ilgi alanı olarak sosyal medya eşsizdir. Sosyal medya herkese sesini duyurma, düşüncelerini ve görüşlerini paylaşma imkânı vermektedir. Sosyal medya toplulukları dünya nüfusunun yarısından fazlasından oluşmakta ve her geçen gün artmaktadır. Sosyal medya herhangi bir konuda insanların kolayca tartışmalara dâhil olabileceği doğal bir çevredir. Bireyler günlük olayları tartışmak için, haberleri yaymak için, ürün ve servisler hakkında yorumlar yapmak için, iş bulmak için hatta market ürünleriyle ilgili sohbet etmek için bile sosyal ağları kullanmaktadırlar. Sosyal medya milyonlarca insanın bir araya gelmeleri ve birbirlerini etkilemeleri için açı bir davettir (Ipscomb, 2010: 74). Sosyal medyanın bir diğer tanımı ise blogların resimlerin, videoların ve daha fazlasının internet üzerinde bireysel kullanıcılar tarafından yayınlandığı, yaratıldığı ve paylaşıldığı bir medya şeklindedir (Strokes, 2010:326). Ayrıca sosyal medya internet kullanıcılarına içerik oluşturmada iş birliğine olanak sağlayan, deneyim ve tecrübelerin paylaşılabildiği ve iş ya da eğlence için bağlantıda kalınabilen online araçlar ve platformlardır (Strauss ve Frost, 2009: 326). Sosyal medyanın sosyal ağlar, bireyler tarafından yayımlanan bloglar, multimedya siteleri, işletmelerin sponsorluğunda kurulan web siteleri, forumlar, podcastler gibi çeşitli türevleri vardır.

Sosyal medya pazarlamacılara tüketiciler ile var olan ilişkilerin kuvvetlendirilmesi fırsatı ile birlikte interaktif bir iletişim ortamını sağlamaktadır. Sosyal medya insanlara görüşlerini açıklayabileceği, fikir alışverişi yapabileceği, sanal bir ortam sağlamaktadır. Tüketicilerin sosyal medyada bir ürünle ilgili olarak yaptıkları yorumlar olumlu ya da olumsuz marka algısı oluşturmakta ve bu yorumlar tüketicilerin kararlarını etkilemektedir (Chung ve Austria, 2010:581). Sosyal medya platformlar1 aynı zamanda tüketicilerin işletmelerle olan ilişkilerinde güçlü ve aktif bir şekilde kendilerini ifade etmelerine olanak tanımakta, tüketicilere seslerini duyurma imkânı vermektedir. Pazarlamacıların ise artık bu seslere duyarsız kalmaları mümkün değildir. Aslında pazarlamacıların \%85'ide sosyal medya pazarlamasının en büyük faydalarından birinin tüketicilerle birlikte 
karşılıklı diyalog kurabilmeleri olduğunu söylemektedirler (Mershon, 2012). Sosyal medya platformları ile birlikte tüketiciler memnuniyetsizliklerini de diğer birçok tüketici ile çok kolay bir şekilde paylaşabilmektedirler. Eskiden tüketiciler ürünler, hizmetler ve firmalar ile ilgili şikâyetlerini yalnızca kendisi çevresindeki kişilerle paylaşırken, artık internet aracılığıyla daha fazla kişiyle şikâyetlerini paylaşabilmektedirler. İnternet ile birlikte bir tüketicinin memnuniyetsizliği ve şikâyetleri birçok tüketici tarafından okunabilmekte ve bu durum birçok tüketicinin satın alma kararını etkileyebilmektedir (Mürütsoy, 2013: 77). Clark (2010) tüketicilerin \%21'inin herhangi bir marka ile ilgili olumsuz yorumlarını dile getirmek ve diğer tüketicileri o markayı almaktan caydırmak için sosyal medyayı kullandıklarını öne sürmüştür.

Sosyal medya tüketicilere herhangi bir konuda sorunların çözülebildiği, herkese açık online platformlarda söz hakkı tanıyarak sadece tüketici tatmini sağlamakla kalmayıp, aynı zamanda hizmet aksaklıklarını ve eksikliklerini de giderici bir rol oynamaktadır (Krishna, vd., 2011). Aynı zamanda sosyal medya tüketicilere özel indirimlerden faydalanma, özel kapmayanlardan yararlanma, işletme ve diğer tüketicilerle etkileşimde bulunma gibi ayrıcalıklara sahip olma imkânı tanır (Clark ve Melancon, 2013:135).

Sosyal medya platformları tüketicilerle önemli bir şekilde ilişkiler kurmayı ve müşteri ilişkilerinde samimiyet derecesinin artırılmasını sağlayarak potansiyel ve halihazırdaki tüketicileri etkilemek ve onları firmaya bağlayabilmek için bir fırsat sunmaktadır (Mersey, vd., 2010). Shaffer ve Garnett (2011) Facebook kullanıcılarının \% 51'inin şirketlerin facebook sayfalarını beğendiğini, bu kullanıcıların facebookta beğenmiş oldukları firmalardan alışveriş yapmaya daha eğilimli olduklarını ve bir şirketin Facebook takipçilerinin \% 84'ünün müşteriye dönüştüğünü bulmuşlardır.

Sosyal medya aynı zamanda ağızdan ağza pazarlama alanında da kendini göstermektedir. Tüketiciler genel olarak reklam gibi kaynaklardan daha çok kişisel deneyim ve yorumlara güvendiğinden ağızdan ağza pazarlama oldukça önemlidir. Gillin (2009) blog yazarlarının bir marka hakkında pozitif yorum yapma oranlarının 6 kat daha fazla olduğunu keşfetmiş ve bir diğer çalışmada ise bireylerin \% 87 sinin bloglardaki tavsiyeler temelinde, $\% 60^{\prime}$ inın ise facebooktaki tavsiyeler temelinde alışverişlerini yapmış oldukları tespit edilmiştir (Collins, 2012). Örneğin birçok firma facebook sayfalarını beğenme karşılığında tüketicilere belli bir oranda indirim yapmakta ya da para puan vermektedir. 


\subsection{Sosyal Medya Araçları}

\subsubsection{Facebook}

Facebook, insanların arkadaşlarıyla, ailesiyle ve meslektaşlarıyla daha etkili bir şekilde iletişim kurmasını sağlayan sosyal bir fayda olarak tanımlamaktadır. Şirket, insanların gerçek sosyal bağlantılarının dijital haritasını yaparak, sosyal diyagram yoluyla bilgi paylaşımını kolaylaştıran teknolojiler geliştirmektedir. Herkes Facebook'a girebilmekte ve güvenilir bir ortamda tanıdıkları insanlarla etkileşim kurabilmektedir (Akar, 2006: 130).

Facebook, bir işletmenin ürünlerinin, markasının ve kendisinin gösterimini rahatlıkla yapmasını sağlayabilen ve bu bağlamda artan üye sayısıyla birlikte topluluk oluşturarak bunu daha geniş kitlelere duyurmayı ve tanıtmayı olanaklı kılan paha biçilemez bir pazarlama ortamı sunmaktadır. Facebook pazarlamacılar için özellikle gerilla tarzı pazarlamacılar için arkadaşlara mesajı yaymada ve yaratıcı bir şekilde hedef izleyicilere ulaşmada viral kanallar grubu sunmaktadır. Bu gerilla tarzı taktiklerin en iyi yanı sıfır maliyetli olmasıdır. (Akar, 2006: 140). Facebook'u etkin kullanan markaya örnek olarak dünyanın en büyük fast-food restronları zinciri olan Mc Donalds verilebilir. Mc Donalds facebook'ta 30 milyona yakın takipçiye sahiptir. Ürünlerini zevkle yiyen müşterilerinin birçok fotoğraflarını birilerini acıktıracak kelimelerle süsleyip takipçileriyle paylaşmaktadır.

\subsubsection{Twitter}

Twitter kullanıcıların birbirleriyle maksimum 140 karakter uzunluğunda olabilen kısa metin tabanlı mesajları kullanarak iletişim kurmasına imkân tanıyan ücretsiz mikroblogging hizmetidir. Twitter, çeşitli aygitlar üzerinde güncellemeleri göndermek ve almak için güçlü araçlar sağlamaktadır. Twitter'ın esas amacı kullanıcıların ne yaptığını 140 karekter ya da daha azıyla cevaplamasıdır (Weinberg, 2009:125). Twitter'ın kullanıcısı olarak kimin güncellemelerini almak istiyorsanız seçebilir takip etmek istediklerinizi belirleyebilirsiniz. Aynı şekilde diğer kullanıcılar da sizin güncellemelerinizi takip etmeyi seçebilirler. Tüm twitler topluluğuna açık bir şekilde veya yarı açık şekilde sadece sizin onayladığınız kullanıcılara ya da birebir özel mesajlar gönderilebilmektedir (Fitton vd., 2009:1). İnsanlar tarafından Twitter'ın iş dünyasındaki amacının keşfedilmesiyle twitter, iş adamları ve pazarlamacılarla dolmaya başlamıştır. Bu gruplar, hedef izleyicilerle ilişki kurmak, hem online hem offline ağ kurma fırsatları 
sağlamak, işletme amaçlarını başarmak ve kişisel amaçlar elde etmek için Twitter yeteneklerini kullanmaktadırlar (Weinberg, 2009:126).

Bazı işletmeler iş yapma şeklini twitter'la değiştirmişlerdir. Zappos (www.zappos.com) , müşteri memnuniyeti konusunda oldukça endişeli olan bir online ayakkabı satıcısıdır. Beklenmeyen bir şekilde müşterileriyle bir iletişim kanalı olarak twitter'ı benimsemiştir ve buradan müşteri hizmetleri sunmaktadır (Lacy, 2010:16).

\subsubsection{Bloglar}

Blog, Weblog isminden türemiştir (Eley ve Tilley, 2009: 81). Bir blog genellikle bireyler ya da gruplar tarafından, son zamanlarda işletmeler tarafından sürdürülen, geniş bir izleyici kitlesi için yorumlar ve fikirler sunan web sitesidir. Tipik bir blogta, sıklıkla resim ve videolarla zenginleştirilen, okuyucular tarafından yorumların takip edildiği bir girişin önemli rolü vardır (Weinberg, 2009: 85). Bloglar, başlangıçta kişisel bir uğraşı olarak düşünülse de blogların gelişmesiyle gitgide daha hızlı bir biçimde işletmelerin ilgi alanına girmiştir. İşletmeler blogosferde kendilerini neyin çok fazla etkilediğini fark etmeye başlamışlardır. Aynı zamanda tüketicilerin kendi ürünleri hakkında ne söylediğinden, rakipleri hakkında ne söylediklerine kadar çoğu şeyi öğrenmektedirler (Newman ve Thomas, 2009: 205-206). İşletme blogları basitçe örgütsel amaçlarla oluşturulan bloglardır (Akar ve Karayel, 2008: 92). İşletme ya da örgütsel bloglar, satışa yardımcı olmayı sağlayan, bunun için bir topluluk oluşturmayı kolaylaştıran ve yaratan, şirket ya da ürünle ilgili olarak söylenti oluşturmaya imkân tanıyan, karşılıklı konuşma formatında web sitelerinin aktif bir türüdür (Akar, 2006: 47).

İşletme bloglarına örnek olarak Starbucks tarafından hazırlanmış olan tüketici geri bildirimlerini ele almada daha iyi hale gelebilmeyi hedefleyen My Starbucks Idea isimli blog verilebilir. Bu blog ile starbucks tüketicilere doğrudan fikirlerini, görüş ve önerilerini ifade etme imkânı sağlayarak tüketicilerin kendi ağızlarından deneyimlerini ve isteklerini öğrenme olanağına sahip olmuştur. Aynı zamanda diğer tüketicilere bu öneri ve fikirleri oylama, eleştirme imkânı sağlayarak tüketicilerin daha katılımcı olmalarını sağlamıştır. Böylelikle starbucks, tüketicileri kendi ağızlarından dinleyerek onları anlayabilme gibi fevkalade bir pazarlama firsatına sahip olmaktadır.

\subsubsection{Sosyal İşaretleme}

Sosyal işaretleme, internette çoğalmakta olan ve hızla popülerlik kazanan en yeni sosyal yazılım teknolojilerinden biridir. Sosyal işaretlemenin amacı- kullanıcıların yararına bilgiye tekrar erişimi kolaylaştırmak ve konunun sunumunu sağlamaktır (Chan, 2009). Sosyal 
işaretleme ile aynı görüşteki insanların birbirleriyle kolaylıkla ilginç ve ilgili içeriği paylaşma imkânı ortaya çıkmaktadır (Stokes, 2009:126). İşletmeler açısından sosyal işaretlemenin önemine baktığımızda, kullanıcıların işletmenin web sitesindeki içeriği nasıl kategorilendirdiğini görmek işletmenin web sitesinin ve şirketin izleyiciler tarafından nasıl algılandığı hakkında bir fikir sahibi olmayı sağlayacaktır (Stokes, 2009:128). Aynı zamanda sosyal işaretleme yoluyla işletmelerin web sitesine gelen ziyaretçi sayısı artırılabilir. Ayrıca sosyal işaretleme sitelerinde yazı sunma, işletmenin web sitesine çok önemli sitelerden link meydana getirmeye yarayabilir.

\section{Medya Paylaşım Siteleri}

Medya paylaşım siteleri inanılmaz derecede popülerdir. Flickr ve Picasa Web Albums gibi siteler üye topluluğuna resimleri yüklemeyi, paylaşmayı, onlara yorum yapmayı ve tartışmayı olanaklı kılmaktadır. Youtube ve benzeri siteler ise aynı şeyleri video içeriği için yapmaktadırlar (Ryan ve Jones, 2009:160). Resim siteleri ürünler için farkındalık yaratmaya yardımcı olabilmesinden dolayı sosyal medya pazarlama için mükemmel araçlardır. Sosyal topluluk oluşturan bu sitelerde mesajı yaymak, işletme ve pazarlama amaçlarına gerçek bir ek değer sağlayabilir (Weinberg, 2009:267). İşletmeler ürün ve hizmetlerini pazarlamak ve sunumlarıyla ilgili mesajları yaymak için videoları kullanmaktadır (Scott, 2007:223). Youtube ürün pazarlaması için mükemmel bir araçtır. Doğru video yüzlerce, binlerce ya da milyonlarca izleme, fan ve önemli olan gerçek dönüşümler sağlayabilmektedir. Ancak önemli olan videoların nasıl pazarlanacağıdır. Eğer bir şeyler acayip, aptalca, eğlenceli, yenilikçi ya da tamamen beklenmedik şeyler ise pazarlama mesajı çok fazla yayılabilir (Weinberg, 2009:287).

\section{Araştırmanın Önemi ve Amacı}

Günümüz dünyasında işletmeler ile tüketiciler arasındaki bağların güçlenmesinde iletişim kanalları önemli yer tutmaktadır. Bu durumu sağlayan araçlardan en önemlisi sosyal medya ağlarıdır. Sosyal medya, işletmelerin tüketiciler ile var olan ilişkilerini kuvvetlendirme fırsatı vermesi ile birlikte interaktif bir iletişim ortamını sağlamaktadır. Sosyal medya tüketicilerin görüşlerini açılayabileceği, fikir alışverişi yapabileceği, sanal bir ortam sağlamaktadır. Tüketicilerin sosyal medyada bir ürünle ilgili olarak yaptıkları yorumlar olumlu ya da olumsuz marka algısı oluşturmakta ve bu yorumlar tüketicilerin kararlarını etkilemektedir. 
$\mathrm{Bu}$ çalışmanın asıl amacı, tüketicilerin algılarının olumlu/ olumsuz yönde etkilenmesi esnasında sosyal medyanın rolünü anlamaya çalışmaktır. $\mathrm{Bu}$ doğrultuda, tüketicilerin satın alma karar süreci aşamalarında (-bir ihtiyacın duyulması, -alternatiflerin belirlenmesi, alternatiflerin değerlendirilmesi, - satın alma kararının verilmesi ve satın alma, satın alma sonrası duygular) davranışlarının hangi boyutlarda etkilendiği ve her bir sosyal medya aracinın (twitter, facebook, forumlar/bloglar, sosyal imleme siteleri, flickr) tüketicilerin satın alma davranışlarını nasıl ve ne ölçüde etkilediğini belirlemek amaçlanmıştır.

\section{Araștırmanın Yöntemi}

Yapılan literatür çalışması neticesinde bu konu ile ilgili yapılmış herhangi bir alan araştırmasına ulaşılamamıştır. Bu sebeple, bu araştırmada keşifsel araştırma yöntemi kullanılmıştır. Keşifsel araştırma yöntemi; bir problemin genel tabiatını ya da iç yüzünü muhtemel karar alternatiflerini ve konuyla ilgili değişkenleri keşfetmeye çalışma durumudur. Bu çalışmalarda temel kıstas, genellikle daha önce çalışılan konu hakkında az bilgi mevcut olması durumunda tercih edilmekte olup, hipotezler kurulmamakta ve model oluşturulmamaktadır (Dokuzer ve İnal, 2008: 381). Bu bilgiden yola çıkarak, yapılan çalışmada model kurulmamıştır ve hipotezler oluşturulmamıştır.

Anakütlenin tamamına ulaşmak hem zaman yönünden hem de maliyet yönünden sıkıntılı olduğu için anakütleyi en iyi temsil edecek örneklem yöntemi seçilmiştir. Bu doğrultuda, yapılan çalışmada Niğde Üniversitesi İ.İ.B.F. eğitim/öğretim gören 418 öğrenciyle, 10.12.201302.01.2014 tarihleri arasında yüz yüze görüşme yöntemi ve ihtimalsiz örnekleme yöntemlerinden kolayca örnekleme yöntemi kullanılmıştır. Kolayca örnekleme yöntemi görüşme yapan uzman kişinin uygun gördüğü kişi ile anketi doldurması olarak ifade edilmiştir (Nakip, 2003: 784).

Anket formu demografik sorularla beraber yedi bölümden oluşmaktadır. Anket formundaki soruların ilk beş bölümü Turku Üniversitesinde (Finlandiya) yapılmış "Sosyal medyanın tüketici davranışları üzerine etkisi" isimli lisans tezinden sağlanmış, diğer bölümler ise araştırmanın içeriği, seçilen örneklem, uygulamanın yeri ve zamanı da göz önünde bulundurularak araştırmacılar tarafından hazırlanmıştır. İlk bölümde öğrencilere günlük hayatta sosyal medya sitelerinden hangisini/ hangilerini kullandıkları sorulmuştur. İkinci bölümdeki sorular ise, öğrencilerin sosyal medya sitelerinde ne kadar zaman geçirdikleri sorulmuştur. Anket formunun üçüncü bölümünde, öğrencileri kitle iletişim araçları ile haftalık olarak ne kadar vakit geçirdikleri öğrenilmeye 
çalışılmıştır. Anket formunun dördüncü bölümünde ürün/hizmet satın almadan önce ürün/hizmet ile bilgi edinmek amacıyla yapılan araştırmalarda sosyal medya araçlarından hangisinin kullanıldığı öğrenilmeye çalışılmıştır. Anket formunun beşinci bölümünde, öğrencilerin satın alma sürecinde sosyal medyanın etkisi ile ilgili sorular sorulmuştur. Bu bölümde sosyal medya ile ilgili Likert ölçeğine uygun sorular sorulmuştur.

Anket formunun altıncı kısmında sosyal medya araçlarının kullanımı ile ilgili sorular sorulmuştur. Anket formunun son bölümünde ise anket katılımcılarının sosyo-ekonomik ve demografik özellikleri ile ilgili dört soru sorulmuştur. Bu dört soru cinsiyet, yaş, eğitim düzeyi, gelir düzeyi ve bölümden oluşmaktadır ve kapalı uçlu sorularla ifade edilmiştir.

\section{Verilerin Analizi}

Yapılan çalışmada elde edilen verilerin analizlerinin yapılmasında, SPSS 20 (Statistical Package for the Social Sciences) istatistik paket programından faydalanılmıştır. SPSS 20 yardımıyla ankette yer alan soruların frekans dağılımı, aritmetik ortalaması ve yüzdeleri hesaplanmıştır. Ayrıca, sosyal medya ile ilgili yargılardaki değişken sayısını azaltmak için faktör analizi kullanılmıştır.

\section{1. Araştırmanın Bulguları ve Değerlendirme}

Niğde Üniversitesi İ.̇̇B.F.'de okuyan öğrencilerden araştırmaya katılan 418 öğrencinin demografik özellikleri ile ilgili sonuçlar ve değerlendirmeler Tablo 1'de gösterilmiştir. 
Tablo 1: Araştırmaya Katılan Öğrencilerin Sosyo-Ekonomik Özelliklerinin Dağılımı

\begin{tabular}{|c|c|c|c|c|c|}
\hline \multicolumn{3}{|c|}{ CINSIIYET } & \multicolumn{3}{|c|}{ AYLIK GELİR } \\
\hline Kadın & 277 & $\% 66,3$ & $0-500 \mathrm{TL}$ & 85 & $\% 17,7$ \\
\hline \multirow{2}{*}{ Erkek } & 141 & $\% 33,7$ & $501 \mathrm{TL}-1000 \mathrm{TL}$ & 265 & $\% 55,1$ \\
\hline & & & 1001 TL ve üzeri & 68 & $\% 27,2$ \\
\hline \multicolumn{3}{|c|}{ EĞİTIM DÜZEYINİZ } & \multicolumn{3}{|c|}{ BÖLÜM } \\
\hline Lisans & 389 & $\% 93,1$ & İşletme & 118 & $\% 28,8$ \\
\hline Yüksek Lisans & 25 & $\% 6$ & İktisat & 196 & $\% 39,7$ \\
\hline Doktora & 4 & $\% 1$ & Kamu Yönetimi & 80 & $\% 24,3$ \\
\hline & & & Siya.Bil.Ulus.İlişkiler & 24 & $\% 7,2$ \\
\hline \multicolumn{3}{|c|}{ YAŞ } & & & \\
\hline 18-ve altı & 19 & $\% 4,5$ & & & \\
\hline $19-21$ & 199 & $\% 47,6$ & & & \\
\hline $22-24$ & 172 & $\% 41,1$ & & & \\
\hline 25 ve üzeri & 27 & $\% 6,5$ & & & \\
\hline
\end{tabular}

Tablo 1'e göre, araştırmaya Niğde Üniversitesi İ.İ.B.F. okuyan toplam 418 öğrencinin katılmış olduğu, bunlardan 277'sinin (\% 66,3) kadın, 141 'inin (\% 33,7) erkek olduğu görülmektedir. Öğrencilerin, aylık gelirlerine göre sınıflandırıldığında, ankete katılan öğrencilerin 265 gibi büyük çoğunluğunun (\% 55,1) 501 TL-1000 TL, 85 öğrencinin ise (\% 17,7), 1000 TL ve üzeri; $68^{\prime}$ inin ise 1001 TL ve üzeri $(\% 27,2)$ arasında dağıldığı, 18 ve altı yaş arasında 19 (\% 4,5) öğrencinin olduğu, 371 öğrencinin $19-24(\%$ 88,7) yaş arasında olduğu,27'sinin ise $(\% 6,5) 25$ yaş ve üzeri olduğu görülmektedir. Ankete katılanların eğitim düzeylerine bakıldığında, 389 öğrencinin (\% 93,1) gibi büyük çoğunluğunun lisans eğitime sahip olduğu, 29 öğrencinin ise $(\%$ 6,9) lisansüstü eğitimine sahip olduğu görülmektedir. Ankete katılanlara okumuş oldukları bölüm açısından bakıldığında, 118'inin (\% 28,8) İşletme bölümünde okuduğu, 196'sının (39,7) İktisat bölümünde okuduğu, 80'inin (\% 24,3) Kamu Yönetimi bölümünde okuduğu ve 24'ünün $(\% 7,2)$ ise Siyaset Bilimi ve Uluslararası İlişkiler bölümünde okuduğu görülmektedir. 
Tablo 2: Araştırmaya Katılan Öğrencilerin Sosyal Medya Sitelerini Takip Etmesi

\begin{tabular}{|l|c|c|}
\hline \multicolumn{1}{|c|}{ Sosyal Medya Siteleri } & Frekans & Yüzde \\
\hline Facebook & 357 & $\% 85,4$ \\
\hline Twitter & 112 & $\% 26,8$ \\
\hline Instgram/ Youtube & 281 & $\% 67,2$ \\
\hline Bloglar/Forumlar & 53 & $\% 12,7$ \\
\hline $\begin{array}{l}\text { Sosyal İmleme Siteleri/Sosyal Haber } \\
\text { (Ör. Reddit, Digg) }\end{array}$ & 58 & $\% 13,9$ \\
\hline
\end{tabular}

Tablo 2'de araştırmaya katılanların sosyal medya sitelerinden hangisini daha çok takip ettikleri ile ilgili soru sorulmuş ve katılımcıların 357'sinin (\% 85,4) Facebook'u, 112'sinin (\%26,8) Twitter, 281'inin $(\% 67,2)$ Instgram/Youtube, 53'ünün Bloglar/Forumlar ve 58'inin $(\% 13,9)$ Soysal İmleme Siteleri/Sosyal Haber (Ör. Reddit, Digg vb.) takip ettikleri sonucu çıkmıştır. Bu sonuçlara göre katılımcıların sosyal medyayı aktif kullandıkları ve özellikle facebook, twitter ve instgram/youtube gibi sosyal medya sitelerini daha çok takip ettikleri tespit edilmiştir. Özellikle işletmeler markalar savaşının yaşandığı günümüz dünyasında tüketicilerin algılarını etkileyerek zihinlerinde ürün/ markaları konumlandırmak istiyorlarsa sosyal medya sitelerine uygun reklam mesajları vermeleri gerekmektedir.

Tablo 3: Sosyal Medya Sitelerinde Haftalık Olarak Geçirilen Zaman

\begin{tabular}{|l|c|c|}
\hline & Frekans & Yüzde \\
\hline 1 saatten az & 48 & $\% 11,4$ \\
\hline 1-3 saat & 106 & $\% 25,4$ \\
\hline 4-6 saat & 106 & $\% 25,4$ \\
\hline 7-9 saat & 58 & $\% 13,9$ \\
\hline 10 saat ve daha fazla & 100 & $\% 23,9$ \\
\hline
\end{tabular}

Tablo 3'te araştırmaya katılanların sosyal medya sitelerinde haftada ne kadar süre zaman harcadıkları tespit edilmeye çalışılmış, katılımcıların $48^{\prime}$ inin $(\% 11,4) 1$ saatten az zaman harcadığ $\breve{1}^{\prime}$ 106'sinın $(\% 25,4) 1-3$ saat zaman harcadığı, 106'sının (\%25,4) 4-6 saat zaman harcadığı, 58'inin (\%13,9) 7-9 saat zaman harcadığı, 100'ünün (\%23,9) 10 saatten fazla zaman harcadığ tespit edilmiştir. Bu sonuçlar göstermektedir ki, katılımcılar sosyal medya sitelerinde çok fazla zaman harcamaktadır. 
Tablo 4: Öğrencilerin Ürün/Hizmet Satın Almadan Önce Ürün Hizmetle İlgili Bilgi Edinmede Sosyal Medyayı Kullanma Sıklıkları

\begin{tabular}{|l|c|c|}
\hline \multicolumn{1}{|c|}{ Sosyal Medya Siteleri } & Ortalama & Std. Sapma \\
\hline Facebook & 3,78 & 1,75 \\
\hline Twitter & 1,86 & 1,28 \\
\hline Bloglar/Forumlar & 2,53 & 1,49 \\
\hline $\begin{array}{l}\text { Sosyal İmleme Siteleri/Sosyal Haber } \\
\text { (Ör. Reddit, Digg) }\end{array}$ & 2,01 & 1,40 \\
\hline Flickr & 1,63 & 1,18 \\
\hline
\end{tabular}

Tablo 4'te katılımcıların ürün/hizmet satın almadan önce ürün hizmetle ilgili bilgi edinmek amaciyla sosyal medyayı kullanma sıklıkları öğrenilmeye çalışılmıştır. Araştırmada 5'li Likert ölçeği kullanılmış olup (1.49'a kadar olan kısım kesinlikle katılmıyorum, 1.50 - 2.49 katılmıyorum, 2.50 - 3.49 fikrim yok, 3.50 - 4.49 katıllyorum, 4.49 - 5.00 kesinlikle katılıyorum) şeklinde ifade edilmiştir. Katılımcıların ürün/hizmet satın almadan önce ürün hizmetle ilgili bilgi edinmek için facebook'u kullanma durumuna katıldiklarmı $(3,78)$ ancak twitter $(1,86)$, sosyal imleme siteleri/sosyal haber (ör. reddit, digg) $(2,01)$ ve flickr $(1,63)$ kullanma durumuna katılmadıkları, bloglar/forumlar $(2,53)$ kullanma durumu hakkında ise fikirlerinin olmadığı sonucu ortaya çıkmıştır. 
Tablo 5: Yargılara Ait Ortalama ve Standart Sapma Değerleri

\begin{tabular}{|c|c|c|c|}
\hline Yarg1 & YARGILAR & ORT & $\begin{array}{l}\text { STD. } \\
\text { SAP }\end{array}$ \\
\hline 1 & $\begin{array}{l}\text { Satın alınmak istenilen ürün/hizmetle ilgili sosyal } \\
\text { medya siteleri aracıllğıyla yeterli bilgi sahibi olurum. }\end{array}$ & 3,55 & 1,075 \\
\hline 2 & $\begin{array}{l}\text { Sosyal medya ürün/hizmet satın alma konusunda } \\
\text { tüketicileri harekete geçiren bir güçtür. }\end{array}$ & 3,78 & 1,010 \\
\hline 3 & $\begin{array}{l}\text { Sosyal medya ürün/hizmet satın alma ya da almama } \\
\text { kararı noktasında tüketicileri etkiler. }\end{array}$ & 3,79 & 1,020 \\
\hline 4 & $\begin{array}{l}\text { Sosyal medyadaki reklamlar, blog yazıları, facebook } \\
\text { sayfaları ve kullanıcı yorumları yeni } \\
\text { markalar/ürünler/servisler deneme konusunda } \\
\text { tüketicileri olumlu yönde etkiler. }\end{array}$ & 3,53 & 1,056 \\
\hline 5 & $\begin{array}{l}\text { Bir ürün/ hizmetle ilgili sosyal medyadaki yorumları } \\
\text { okuduktan sonra o ürün/hizmeti almayı düşünürüm. }\end{array}$ & 3,35 & 1,056 \\
\hline 6 & $\begin{array}{l}\text { Tüketicilerin bir ürün/hizmet satın alma konusunda } \\
\text { tereddütleri varsa sosyal medyadaki bilgilere güvenir. }\end{array}$ & 3,45 & 1,099 \\
\hline 7 & $\begin{array}{l}\text { Ürün/ hizmet satın aldıktan sonra sosyal medya } \\
\text { aracılığıyla ürün/hizmete iliş̧kin görüşlerimi } \\
\text { arkadaşlarımla ya da diğer kullanıcılar la paylaşırım. }\end{array}$ & 3,59 & 1,139 \\
\hline 8 & $\begin{array}{l}\text { Sosyal medyada bir ürün, marka ya da servisle ilgili } \\
\text { olumlu görüşler/eleştiriler okuduktan sonra o } \\
\text { ürün/marka/servisle ilgili görüşlerim değişir. }\end{array}$ & 3,03 & 1,083 \\
\hline 9 & $\begin{array}{l}\text { Sosyal medyadaki geri bildirimler (eleştiri/yorum/blog } \\
\text { yazıları) alışveriş kararımı olumlu yönde etkiler. }\end{array}$ & 3,51 & 1,089 \\
\hline 10 & $\begin{array}{l}\text { Sosyal medya, tüketicilerin birbirleriyle ve işletmelerle } \\
\text { iletişim kurabilmelerinde etkili, güçlü ve hızlı bir } \\
\text { ortam sağlar. }\end{array}$ & 3,58 & 1,034 \\
\hline 11 & $\begin{array}{l}\text { Ürünler veya servislerle ilgili sosyal medyada yer alan } \\
\text { bilgiler geleneksel medyadaki bilgilere göre daha } \\
\text { güvenilirdir. }\end{array}$ & 3,42 & 1,066 \\
\hline 12 & $\begin{array}{l}\text { Sosyal medya tüketicilerin satın alma kararını daha da } \\
\text { karmaşık hale getirir. }\end{array}$ & 3,78 & 0,980 \\
\hline 13 & $\begin{array}{l}\text { Sosyal medya geleneksel medyaya nazaran (TV vb.) } \\
\text { yeni ürünler/hizmetler/markalar konusunda } \\
\text { tüketicinin dikkatini daha fazla çeker. }\end{array}$ & 2,94 & 1,088 \\
\hline 14 & $\begin{array}{l}\text { Tüketicilerin bir ürün/hizmet satın alma konusunda } \\
\text { tereddütleri varsa sosyal medyadaki bilgilere güvenir. }\end{array}$ & 2,93 & 1,122 \\
\hline
\end{tabular}


Tablo 5'te katılımciların sosyal medya ile ilgili yargılara katılma dereceleri dikkate alındığında, "satın alınmak istenilen ürün/hizmetle ilgili sosyal medya siteleri aracilığıyla yeterli bilgi sahibi olurum" $(3,55)$, "sosyal medya ürün/hizmet satın alma konusunda tüketicileri harekete geçiren bir güçtür" (3,78), "sosyal medya ürün/hizmet satın alma ya da almama kararı noktasında tüketicileri etkiler" (3,79), "sosyal medyadaki reklamlar, blog yazıları, facebook sayfaları ve kullanıcı yorumları yeni markalar/ürünler/servisler deneme konusunda tüketicileri olumlu yönde etkiler" $(3,53)$, "ürün/ hizmet satın aldıktan sonra sosyal medya aracılığıyla ürün/hizmete ilişkin görüşlerimi arkadaşlarımla ya da diğer kullanıcılar la paylaşırım" (3,59), "sosyal medyadaki geri bildirimler (eleştiri/yorum/blog yazıları) alışveriş kararımı olumlu yönde etkiler" (3,51), "sosyal medya, tüketicilerin birbirleriyle ve işletmelerle iletişim kurabilmelerinde etkili, güçlü ve hızlı bir ortam sağlar" $(3,42)$ yargılarına katıldıkları, "sosyal medya geleneksel medyaya nazaran (TV vb.) yeni ürünler/hizmetler/markalar konusunda tüketicinin dikkatini daha fazla çeker" $(3,35)$, "tüketicilerin bir ürün/hizmet satın alma konusunda tereddütleri varsa sosyal medyadaki bilgilere güvenir" $(3,45)$, "sosyal medyada bir ürün, marka ya da servisle ilgili olumlu görüşler/eleştiriler okuduktan sonra o ürün/marka/servisle ilgili görüşlerim değişir" (3,03), "ürünler veya servislerle ilgili sosyal medyada yer alan bilgiler geleneksel medyadaki bilgilere göre daha güvenilirdir" $(3,42)$, sosyal medya tüketicilerin satın alma kararını daha da karmaşık hale getirir $(3,78)$, "sosyal medya geleneksel medyaya nazaran (TV vb.) yeni ürünler/hizmetler/markalar konusunda tüketicinin dikkatini daha fazla çeker" $(2,94)$, "tüketicilerin bir ürün/hizmet satın alma konusunda tereddütleri varsa sosyal medyadaki bilgilere güvenir" $(2,93)$ yargılarna ise fikrim yok cevabını vermişlerdir.

Tablo 6: Öğrencilerin Twitter Kullanma Sıklıkları

\begin{tabular}{|l|l|l|l|}
\hline Yargi & \multicolumn{1}{|c|}{ YARGILAR } & ORT & $\begin{array}{c}\text { STD. } \\
\text { SAP }\end{array}$ \\
\hline 1 & Kendi profilimde paylaşımlarda bulunurum. & 2,35 & 1,729 \\
\hline 2 & Takip ettiğim kullanıcıların yorumlarını okurum. & 2,54 & 1,692 \\
\hline 3 & $\begin{array}{l}\text { Takip ettiklerim ve takip edenlerimle iletişim } \\
\text { kurarım (mesajlaşırım) }\end{array}$ & 2,31 & 1,590 \\
\hline 4 & Diğer kullanıcıların iletilerini paylaşırım. (retweet) & 2,01 & 1,458 \\
\hline
\end{tabular}

Tablo 6'da katılımcların twitter kullanılma sıklıkları öğrenilmeye çalışılmıştır. Bu yargılara ilişkin vermiş oldukları cevaplar (ortalamalar) dikkate alındığında; "kendi profilimde paylaşımlarda bulunurum" $(2,35)$, 
"takip ettiklerim ve takip edenlerimle iletişim kurarım (mesajlaşırım)" $(2,31)$, "diğer kullanıcıların iletilerini paylaşırım (retweet)" (2,01) yargılarına katılmadıkları, "takip ettiğim kullanıcıların yorumlarını okurum" $(2,54)$ yargısı hakkında ise fikirlerinin olmadığı sonucu çıkmıştır.

Tablo 7: Öğrencilerin Sosyal A ̆g (Facebook, Google vb) Kullanma Sıklıkları

\begin{tabular}{|c|c|c|c|}
\hline Yarg1 & YARGILAR & ORT & $\begin{array}{l}\text { STD. } \\
\text { SAP }\end{array}$ \\
\hline 1 & $\begin{array}{l}\text { Arkadaşlarımın durum güncellemesini ve içerik } \\
\text { paylaşımlarını izlerim. }\end{array}$ & 3,63 & 1,480 \\
\hline 2 & $\begin{array}{l}\text { Beğendiğim marka veya firmaların sayfasına üye } \\
\text { olurum. }\end{array}$ & 3,40 & 1,570 \\
\hline 3 & Grup oluşturur ve yöneticiliğini yaparım. & 2,08 & 1,473 \\
\hline 4 & Gruplara üye olurum. & 3,02 & 1,542 \\
\hline 5 & $\begin{array}{l}\text { Gruplara üye olmaları için arkadaşlarımı davet } \\
\text { ederim. }\end{array}$ & 2,30 & 1,562 \\
\hline
\end{tabular}

Tablo 7'de katılımcıların sosyal ağ (facebook, google vb.) kullanılma sıklıkları öğrenilmeye çalışılmıştır. Bu yargılara ilişkin vermiş oldukları cevaplar (ortalamalar) dikkate alındığında; "arkadaşlarımın durum güncellemesini ve içerik paylaşımlarını izlerim" $(3,63)$ "beğendiğim marka veya firmaların sayfasına üye olurum" $(3,40)$ yargılarına katıldıklarl; gruplara üye olurum $(3,02)$ yargısı hakkında fikirleri olmadı ğı, gruplara üye olmaları için arkadaşlarımı davet ederim (2,30), grup oluşturur ve yöneticiliğini yaparım $(2,08)$ yargılarına ise katılmadıkları sonucu çıkmıştır.

Tablo 8: Öğrencilerin Medya Paylaşım Siteleri (Youtube, vb.) Kullanma Sıklıkları

\begin{tabular}{|l|l|l|l|}
\hline Yarg1 & \multicolumn{1}{|c|}{ YARGILAR } & ORT & $\begin{array}{c}\text { STD. } \\
\text { SAP }\end{array}$ \\
\hline 1 & $\begin{array}{l}\text { Medya paylaşım sitelerindeki reklamlar TV } \\
\text { reklamlarını göre daha etkilidir. }\end{array}$ & 2,82 & 1,537 \\
\hline 2 & $\begin{array}{l}\text { Medya paylaşım sitelerinde izlemek istediğim video } \\
\text { başlamadan önce yayınlanan reklamların tamamını } \\
\text { izlerim. }\end{array}$ & 2,01 & 1,342 \\
\hline 3 & $\begin{array}{l}\text { Medya paylaşım sitelerindeki tanıtıcı reklamlar satın } \\
\text { alma davranısımı olumlu yönde etkiler. }\end{array}$ & 2,53 & 1,424 \\
\hline
\end{tabular}


Tablo 8'de katılımciların medya paylaşım siteleri (youtube, vb.) kullanılma sıklıkları öğrenilmeye çalışılmıştır. Bu yargılara ilişkin vermiş oldukları cevaplar (ortalamalar) dikkate alındığında; "medya paylaşım sitelerinde izlemek istediğim video başlamadan önce yayınlanan reklamların tamamını izlerim" $(2,01)$ yargısına katılmadıkları, "medya paylaşım sitelerindeki tanıtıcı reklamlar satın alma davranışımı olumlu yönde etkiler" (2,53), medya paylaşım sitelerindeki reklamlar TV reklamlarını göre daha etkilidir $(2,01)$ yargıları hakkında ise fikirlerinin olmadığı sonucu çıkmıştır.

\subsection{Araştırma Yöntemi}

\subsubsection{Faktör ve Güvenilirlik Analizi}

Yapılan araştırma sonucu elde edilen veri setine SPSS 20.00 programından faydalanılarak keşifsel faktör analizi uygulanmıştır. Yapılan keşifsel faktör analizi sonucunda bütün değişkenlere KMO (Kaiser-MeyerOlkin) ve Barlett testleri yapılmış, analize tabi tutulan değişkenlerin sonucuna bakılarak faktör analizine uygun olup olmadıkları test edilmiştir. Bütün değişkenlerin, $\mathrm{KMO}$ testi $0,5^{\prime}$ den büyük olması gerekmektedir (Albayrak vd., 2005: 322). Gözlenen korelasyon katsayılarının büyüklüğü ile kısmı korelasyon katsayılarının büyüklügü karşılaştırılır. Bu testin değeri küçük çıkarsa, çift olarak değişkenler arasındaki korelasyon ilişkisinin diğer değişkenlerce açıklanmayacağını gösterir. Bu durumda faktör analizine devam etmek doğru olmaz. KMO bir oran olup \%60'ın üstünde olması arzulanır (Nakip, 2003:408). Yapılan çalışmada KMO testi sonucu \% 84,4 olarak belirlenmiştir. Ayrıca, özdeğeri (Eigenvalue) 1'den büyük olan faktörler anlamlı kabul edilir (Albayrak vd., 2005: 322) ve Barlett testinin ise 0.05 'den küçük olması gerekmektedir.

Genellikle Cronbach's Alfa $(\alpha)$ Katsayısının alt limiti olarak 0,70 kabul edilmektedir. Ancak, keşfedici araştırmalarda Cronbach's Alfa $(\alpha)$ Katsayısının 0,60'ın üstünde olması ölçeğin güvenilir olduğunu gösterir (Hair vd., 1998: 118; Yaraş, 2004: 85).

Cronbach's Alfa $(\alpha)$ Katsayısına bağlı olarak ölçeğin güvenilirliği aşağıdaki tablodaki gibi yorumlanmıştır (Albayrak vd., 2005: 405):

Tablo 9: Cronbach's Alfa $(\alpha)$ Katsayısı

$0,00 \leq \alpha \leq 0,40$ ise ölçek güvenilir değil

$0,4<\alpha \leq 0,6$ ise ölçeğin güvenilirliği düşük

$0,6<\alpha \leq 0,8$ ise ölçek oldukça güvenilir

$0,8<\alpha \leq 1,00$ ise ölçek yüksek derecede güvenilir 
Kaynak: ALBAYRAK, A. Sait; Abdullah Eroğlu; Şeref Kalaycl; Engin Küçüksille; Belma Ak vd. (2005) SPSS Uygulamalı Çok Değişkenli İstatistik Teknikleri, Asi Yayın Dağıtım LTD.ŞTİ, 1. Baskı, Ankara.

Tablo 10: KMO ve Barlett Test Sonuçları

\begin{tabular}{|l|l|}
\hline Kaiser Meyer Olkin (KMO) & 0,844 \\
\hline Barlett testi Yaklaşım Ki kare Değeri & 1370,995 \\
Serbestlik Derecesi (df.) & 91 \\
Anlamlıllk Düzeyi (sign.) & .000 \\
\hline
\end{tabular}

Tablo 10' da KMO testi sonucu \% 84,4 olarak belirlenmiştir. KMO testinin \% 60'dan büyük ve Bartlett testi sonucunun $(0,00<0,05)$ ve değişkenler arasında oluşan korelasyon katsayılarının \% 30 ve üzerinde olması durumu, veri setinin faktör analizine uygun olduğu sonucunu vermektedir. Bu çalışmada, KMO (\% 84,4) ve Bartlett testi sonuçlarına göre bu bilgiler ışığında veri setinin faktör analizine uygun olduğu görülmektedir. Ayrıca ölçeklere ait Cronbach's Alpha katsayılarına bakıldığında, katsayıların 0,744 ile 0,642 arasında değiştiği ve tanımlayıcı araştırmalarda 0,60 değeri kabul edilmesinden dolayı ölçekler güvenilirdir.

Tablo: 11 Sosyal Medya Değişkenlerine Yönelik Faktör Analizi Sonuçları

\begin{tabular}{|c|c|c|c|c|c|}
\hline Değişkenler & $\begin{array}{l}\text { Faktör } \\
\text { Yükleri }\end{array}$ & Özdeğer & $\begin{array}{l}\text { Açıklan } \\
\text { an } \\
\text { Varyans } \\
\text { Yüzdesi }\end{array}$ & $\begin{array}{l}\text { Ortalam } \\
\text { a }\end{array}$ & $\begin{array}{l}\text { Cronba } \\
\text { ch's } \\
\text { Alpha }\end{array}$ \\
\hline $\begin{array}{l}\text { Faktör 1:Sosyal } \\
\text { Medyanın } \\
\text { Etkileme Gücü }\end{array}$ & & \multirow{3}{*}{4,348} & \multirow{3}{*}{31,059} & \multirow{3}{*}{3,68} & \multirow{3}{*}{0,744} \\
\hline $\begin{array}{l}\text { Sosyal medya } \\
\text { ürün/hizmet satın } \\
\text { alma ya da almama } \\
\text { kararı noktasında } \\
\text { tüketicileri etkiler }\end{array}$ & ,774 & & & & \\
\hline $\begin{array}{l}\text { Sosyal medya } \\
\text { ürün/hizmet satın } \\
\text { alma konusunda } \\
\text { tüketicileri harekete } \\
\text { geçiren bir güçtür }\end{array}$ & ,763 & & & & \\
\hline
\end{tabular}




\begin{tabular}{|c|c|c|c|c|c|}
\hline $\begin{array}{l}\text { Satın alınmak } \\
\text { istenilen } \\
\text { ürün/hizmetle ilgili } \\
\text { sosyal medya } \\
\text { siteleri aracılığıyla } \\
\text { yeterli bilgi sahibi } \\
\text { olurum }\end{array}$ & 617 & & & & \\
\hline $\begin{array}{l}\text { Sosyal medyadaki } \\
\text { reklamlar, blog } \\
\text { yazıları, facebook } \\
\text { sayfaları ve } \\
\text { kullanıcı yorumları } \\
\text { yeni } \\
\text { markalar/ürünler/s } \\
\text { ervisler deneme } \\
\text { konusunda } \\
\text { tüketicileri olumlu } \\
\text { yönde etkiler }\end{array}$ & ,583 & & & & \\
\hline $\begin{array}{l}\text { Sosyal medya, } \\
\text { tüketicilerin } \\
\text { birbirleriyle ve } \\
\text { işletmelerle iletişim } \\
\text { kurabilmelerinde } \\
\text { etkili, güçlü ve hızlı } \\
\text { bir ortam sağlar }\end{array}$ & ,553 & & & & \\
\hline $\begin{array}{l}\text { Faktör 2: Sosyal } \\
\text { Medyaya Güven }\end{array}$ & & \multirow[b]{2}{*}{1,316} & \multirow[b]{2}{*}{19,397} & \multirow[b]{2}{*}{3,31} & \multirow[b]{2}{*}{0,678} \\
\hline $\begin{array}{l}\text { Ürünler veya } \\
\text { servislerle ilgili } \\
\text { sosyal medyada yer } \\
\text { alan bilgiler } \\
\text { geleneksel } \\
\text { medyadaki } \\
\text { bilgilere göre daha } \\
\text { güvenilirdir }\end{array}$ & 705 & & & & \\
\hline
\end{tabular}




\begin{tabular}{|c|c|c|c|c|c|}
\hline $\begin{array}{l}\text { Tüketicilerin bir } \\
\text { ürün/hizmet satın } \\
\text { alma konusunda } \\
\text { tereddütleri varsa } \\
\text { sosyal medyadaki } \\
\text { bilgilere güvenir }\end{array}$ & 662 & & & & \\
\hline $\begin{array}{l}\text { Sosyal medyadaki } \\
\text { geri bildirimler } \\
\text { (eleştiri/yorum/blo } \\
\text { g yazıları) alışveriş } \\
\text { kararımı olumlu } \\
\text { yönde etkiler }\end{array}$ & 610 & & & & \\
\hline $\begin{array}{l}\text { Sosyal medyada bir } \\
\text { ürün, marka ya da } \\
\text { servisle ilgili } \\
\text { olumlu } \\
\text { görüssler/eleştiriler } \\
\text { okuduktan sonra o } \\
\text { ürün/marka/servisl } \\
\text { e ilgili görüşlerim } \\
\text { değişir }\end{array}$ & ,521 & & & & \\
\hline $\begin{array}{l}\text { Faktör 3: Sosyal } \\
\text { Medyanın } \\
\text { Etkileşim Gücü }\end{array}$ & & \multirow[t]{2}{*}{1,185} & \multirow[t]{2}{*}{18,462} & \multirow[t]{2}{*}{3,08} & \multirow[t]{2}{*}{0,642} \\
\hline $\begin{array}{l}\text { Bir ürün/ hizmetle } \\
\text { ilgili sosyal } \\
\text { medyadaki } \\
\text { yorumları } \\
\text { okuduktan sonra o } \\
\text { ürün/hizmeti } \\
\text { almayı düşünürüm }\end{array}$ & 696 & & & & \\
\hline
\end{tabular}




\begin{tabular}{|l|l|l|l|l|}
\hline Ürün/ hizmet satın &, 584 & & & \\
aldıktan sonra & & & & \\
sosyal medya & & & & \\
aracilığılya & & & & \\
ürün/hizmete & & & & \\
ilişkin görüşlerimi & & & & \\
arkadaşlarımla ya & & & & \\
da diğer & & & & \\
kullanıcılarla & & & & \\
paylaşırım & & & & \\
\hline
\end{tabular}

Çalışmada birinci faktör, "Sosyal Medyanın Etkileme Gücü" olarak adlandırılmıştır. Sosyal Medyanın Etkileme Gücü faktörünün özdeğeri 4,338'tir ve toplam varyansın \%31,059'unu aç1klamaktadır. "Sosyal medyanın etkileme gücü" ortalama değeri 3,68 olarak çıkmıştır. Cronbach's Alpha değeri ise (\% 74) olarak çımış ve oldukça güvenilirdir.

Faktör analizi sonucunda elde edilen ikinci faktör, "Sosyal Medyaya Güven" olarak adlandırılmıştır. İkinci faktörün özdeğeri, 1,316'dır ve toplam varyansın \%19,397'sini açıklamaktadır. "Sosyal Medyaya Güven" ortalama değeri 3,31 olarak çıkmıştır. Cronbach's Alpha değeri ise (\% 67,8) olarak çıkmış ve oldukça güvenilirdir.

Faktör analizi sonucunda elde edilen üu̧üncü faktör, "Sosyal Medyanın Etkileşim Gücü” olarak adlandırılmıştır. Üçüncü faktörün özdeğeri, $1,185^{\prime}$ dir ve toplam varyansın \%18,462'sini açıklamaktadır"Sosyal Medyanın Etkileşim Gücü" ortalama değeri 3,08 olarak çıkmıştır. Cronbach's Alpha değeri ise $(\%$ 64,2) olarak çıkmış ve oldukça güvenilirdir.

\section{Sonuç ve Öneriler}

Rekabet savaşlarının her geçen gün arttığ günümüz dünyasında markalar, etkili/ farklı ürünler ve özellikle hizmetler işletmeler için çok önemli bir silah haline gelmiştir. Bu küresel rekabet ortamında ayakta kalabilmek ve kedisini ispat etmek isteyen işletmelerin, güçlü marka oluşturma, tüketicilerin istek ve ihtiyaçlarını anlama ve devamlılıklarını sürdürebilmeleri için modern pazarlama anlayışını benimsemeleri ve anında problemlere çözüm üretmeleri gerekmektedir. Günümüzde problemlere çözüm üretmede en etkili araçlardan biri sosyal medyadır. Bu doğrultuda, işletmeler tüketicilerin algılarını etkileyen faktörleri daha etkin ve verimli kullanmak için tutundurma karması bileşenlerinden e-pazarlamanın önemli bir unsuru olan sosyal medya araçlarını rekabet gücü olarak 
kullanmaktadırlar. Sosyal medya, kullanıcılarının kendilerini daha iyi ifade ettikleri, etkileşim içinde oldukları kullanıcılar ile fikir ve görüşlerini paylaştıkları online bir ortam olarak ifade edilmektedir.

$\mathrm{Bu}$ çalışmada, tüketicilerin algılarını etkileyen faktörlerde sosyal medyanın rolü incelenmiştir. Bunun için, Niğde Üniversitesi İ.İ.B.F. eğitim/öğretim gören 418 öğrenciyle 10.12.2013-02.01.2014 tarihleri arasında yüz yüze görüşme yöntemi ve ihtimalsiz örnekleme yöntemlerinden kolayca örnekleme yöntemi kullanılmıştır.

Yapılan analizler çerçevesinde, tüketicilerin demografik ve sosyoekonomik özelliklerinin dağılımına bakılmış katılımcıların bayan, gelir düzeylerinin çoğunlukla 501 TL-1000 TL arasında dağıldığı ve çoğunluğunun lisans öğrencilerinden oluştuğu belirlenmiştir.

Araştırmaya katılan öğrencilerin sosyal medya sitelerinden hangisini daha çok takip ettikleri ile ilgili soruya büyük çoğunluğunun kullandığı ve genelde Facebook ve Twitter kullandıkları belirlenmiştir. Katılımcilar sosyal medya sitelerinde haftada 1 saatten fazla zaman geçirdiklerini ve ürün/hizmet satın almadan önce ürün/hizmetle ilgili bilgi edinmede sosyal medya sitelerinden Facebook'u daha çok bu amaçla kullanmış oldukları tespit edilmiştir.

Araştırmaya katılan katılımcıların, twitter kullanılma sıklıkları öğrenilmeye çalışılmış ve bu yargılara ilişkin vermiş oldukları cevaplar (ortalamalar) dikkate alındığında; "kendi profilimde paylaşımlarda bulunurum" $(2,35)$, "takip ettiklerim ve takip edenlerimle iletişim kurarım (mesajlaşırım)" (2,31), "diğer kullanıcıların iletilerini paylaşırım (retweet)" $(2,01)$ yargılarına katılmadıkları, "takip ettiğim kullanıcıların yorumlarını okurum" $(2,54)$ yargısı hakkında ise fikirlerinin olmadığı tespit edilmiştir.

Araştırmaya katılan katılımcıların sosyal ağ (facebook, google vb.) kullanılma sıklıkları öğrenilmeye çalışılmış ve bu yargılara ilişkin vermiş oldukları cevaplar (ortalamalar) dikkate alındığında; "arkadaşlarımın durum güncellemesini ve içerik paylaşımlarını izlerim" $(3,63)$ "beğendiğim marka veya firmaların sayfasına üye olurum" $(3,40)$ yargılarına katıldıklarl; gruplara üye olurum $(3,02)$ yargısı hakkında fikirleri olmadığı, gruplara üye olmaları için arkadaşlarımı davet ederim $(2,30)$, grup oluşturur ve yöneticiliğini yaparım $(2,08)$ yargılarına ise katılmadıkları sonucu çıkmıştır.

Araştırmaya katılan katılımcıların medya paylaşım siteleri (youtube, vb.) kullanılma sıklıkları öğrenilmeye çalışılmış ve bu yargılara ilişkin vermiş oldukları cevaplar (ortalamalar) dikkate alındığında; "medya paylaşım sitelerinde izlemek istediğim video başlamadan önce yayınlanan 
reklamların tamamını izlerim" $(2,01)$ yargısına katılmadıkları, "medya paylaşım sitelerindeki tanıtıcı reklamlar satın alma davranışımı olumlu yönde etkiler" (2,53), medya paylaşım sitelerindeki reklamlar TV reklamlarını göre daha etkilidir $(2,01)$ yargıları hakkında ise fikirlerinin olmadığı sonucu çıkmıştır.

Yapılan analizler sonucunda, araştırmada kullanılan tüm değişkenlerin geçerlik ve güvenilirliğinin yüksek olduğu belirlenmiştir. Ayrıca yapılan faktör analizi sonucunda, en büyük yüke sahip faktörün "sosyal medyanın etkileme gücü" olduğu, bu faktörü sirasıyla, "sosyal medyaya güven" ve "sosyal medyanın etkileşim gücü" faktörlerinin izlediği ortaya konulmuştur.

Tüketicilerin algılarını etkileyen faktörlerde sosyal medyanın yerine yönelik yapılan bu çalışmadan elde edilen sonuçların yorumlanmasına ve kullanılmasına yönelik bilgiler, hem bu alanda akademik çalışma yapmayı düşünen kişilere, hem de işletme yöneticilerine kararlarında büyük katkı sağlayacaktır.

\section{Kaynakça}

Albayrak A. S., E. Abdullah, K. Şeref vd. SPSS Uygulamalı Çok Değişenli İstatistik Teknikleri, 1. Baskı, Asil Yayın Dağıtım Ltd.Şti., Ankara 2005.

Akar, E. Blogla Pazarlama. İstanbul: TİEM, 2006.

Akar, E., Karayel M., "Transformation of Traditional Marketing Mix in Blog Marketing, International Conference On Social Sciences", ICSSİzmir, 2008 s. 91-103.

Akçay, E. (2013), "Kolluğun Gözlem ve Karar Verme Becerileri", Güvenlik Bilimleri Dergisi, s. 61.

Chan, L. M., "Social Bookmarking And Subject Indexing, Satellite PreConference, IFLA Classification and Indexing Section", Looking at the Past and Preparing for the Future, 20-21 August Florence, Italy 2009.

Chung C., Austria K. Proceedings of the Northeast Business \& Economics Association, 2010, s.581.

Collins, J., Women in Social Media in. Retrieved from http://www.blogher.com/women-and-social-media-2012.

Curtis A. (2011), The brief history of socialmedia. Retrieved from http://www.uncp.edu/home/acurtis/NewMedia/SocialMedia/Social MediaHistory.html. 
Deepa N., Deshmukh S. (2013), "Social Media Marketing: The Next Generation Of Business Engagement", IJMRR/ Feb 2013, Vol. 3, Issue 2, Article No-12/2461-2462.

Elley, B., S. Tilley, Online Marketing Inside Out, First Edition, SitePoint Pty. Ltd.Canada, 2009.

Dokuzer Bülent, M. Emin İnal (2008), Örnek Edinmenin İşletmeler Tarafından Bilinirliliği ve Uygulanırlığının Saptanmasına Yönelik Bir Araştırma: Niğde Örneği, Süleyman Demirel Üniversitesi İ̈BF Dergisi, C.13, S.2, s. 371-401.

Fitton, L., M.Gruen ve L. Poston. Twitter for Dummies, Wiley Publishing, Inc:Indiana, 2009.

Gillin, P.. Secrets of Social Media Marketing: How to Use Online Conversations and Consumer Communities to Turbo-Charge Your Business. Fresno, CA: Quill Driver Books.

Ipscomb, J., “What is social media?" Dental Economics, Vol.100, No 4, $2010 \mathrm{~s}$. 74.

İslamoğlu, A.H., R. Altunışık. Tüketici Davranışları, Beta Basım A.Ş., İstanbul, 2010.

Hair, F. Joseph, Ronald R. Tahtam, William C. Anderson Multivariate Data Analysis, 5. Th. Ed., Prentice - Hall, Englewood Cliffs., 1998.

Helvacı, M. Akif., "Performans Yönetimi Sürecinde Performans Değerlendirmenin Önemi", Ankara Üniversitesi Eğitim Bilimleri Fakültesi Dergisi, 2002 s.161.

Karabulut, M. Tüketici Davranışları, İşletme İktisadı Enstitüsü Yayını, İstanbul, 1998.

Keklik, B., "Öğretim Üyelerinin Dış Görünüşlerinin Öğrenciler Tarafından Algılanma Biçiminin İncelenmesine Yönelik Bir Araştırma", Uluslararası Alanya İşletme Fakültesi Dergisi, 2012 s.131.

Krishna, A., Dangayach, G. Jain, R., "A Conceptual Framework for the Service Recovery Paradox". The Marketing Review, Vol.11, No.1, (2011) s. 41-56.

Lacy, K., Twitter Marketing for Dummies, Wiley Publishing, Inc: Indiana, 2010.

Lee, E., "Impacts of Social Media on Consumer Behavior", Bachelor's Thesis, Turku University of Applied Sciences, 2013,

Mersey, M., Calder, "Engagement with Online Media". Journal of Media Business Studies, Vol.7 No.2, 2010s. 37-56.

Mershon, P. Social Media Marketing Trends: New Research. Social Media Examiner,2012. 
Mürütsoy, M., “İnternet Tüketicisinin Satın Alma Davranışları Üzerine Bir Araştırma", Yayınlanmamış Yüksek Lisans Tezi, Niğde Üniversitesi Sosyal Bilimler Enstitüsü, Niğde, 2013.

Nakip, M. Pazarlama Araştırması, Seçkin Yayıncılık, Ankara, 2003.

Newman, A.C. Thomas J.G., Enterprise 2.0 Implementation, Mc-Graw Hill:New York, 2009.

Odabaşı Y., G. Barış, Tüketici Davranışları, MediaCat Yayınları, Ankara, 2002.

Ryan, D., Jones C., Understanding Digital Marketing, Kogan Page:London, 2009.

Scott, D.M., The New Rules of Marketing and PR, John Wiley\&Sons, Inc,:New Jersey, 2007.

Shaffer, J., Garnett, M. (2011), Monetizing Social Media. Printing Impressions, $54(1)$, s. 22.

Stokes, R., eMarketing the Essential guide to online marketing, 2nd edition, Quirk eMarketing (Pty9 Ltd), 2009.

Strauss, J., R. Frost, E-Marketing 5th Ed. Upper Saddle River, NJ: Prentice Hall, 2009.

Strokes, R., e-Marketing: The Essential Guide to Online Marketing. Cape Town, South Africa: Quirk e-Marketing Ltd., 2009.

Yaraş, Eyüp, "Marka Değeri Algılaması ve Pazarlama Karması İlişkisi", Yayınlanmamış Doktora Tezi, İstanbul Üniversitesi Sosyal Bilimler Enstitüsü, İstanbul, 2004.

Weinberg, T., The New Community Rules: Marketing on the Social Web, O'reilly: California, 2009.

http://www.msxlabs.org/forum/psikoloji-ve-psikiyatri

(ErişimTarihi: 08.01.2014).

http://hbogm.meb.gov.tr/modulerprogramlar/kursprogramlari

(Erişim Tarihi: 04.01.2014). 
M. TOKSARI, M. MÜRÜTSOY, M. BAYRAKTAR 28 